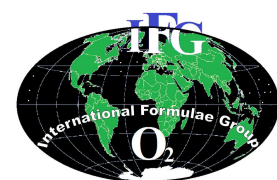

\title{
Effect of experimental trypanosomosis on body weight, packed cells volume and reproductive characteristics in Gudali zebu and Namchi taurine bulls
}

\author{
Jean Pierre Mingoas KILEKOUNG ${ }^{1 *}$, Joseph TCHOUMBOUE ${ }^{2}$, André Zoli PAGNAH ${ }^{1}$, \\ Youssouf Mfopit MOULIOM ${ }^{3}$ and Jean Ebene NYOUNGUI ${ }^{3}$ \\ ${ }^{1}$ School of Veterinary Medicine and Sciences, University of Ngaoundéré, \\ P.O. Box 454 Ngaoundéré, Cameroon. \\ ${ }^{2}$ Department of Animal Production, Faculty of Agronomy and Agricultural Sciences, \\ University of Dschang, P.O. Box 222 Dschang, Cameroon. \\ ${ }^{3}$ Institute of Agricultural Research for Development, Wakwa, P.O. Box 65 Ngaoundéré, Cameroon. \\ "Corresponding author; E-mail: jmingoas@yahoo.fr, Tél. (237) 52708420 /(237) 94516394
}

\begin{abstract}
Thirty-two young Gudali zebus and Namchi taurine bulls were infected to assess the effect of trypanosomosis on body weight (BW), packed cells volume (PCV) and some reproductive characteristics such as scrotal circumference (SC) and Testosterone (T), Luteinizing Hormone (LH) and Follicle Stimulating Hormone (FSH) blood levels. Gudali zebus are known to be trypanosusceptible, while Namchi taurine are trypanotolerant. Trypanosomes were detected in the blood stream 14 days post infection. Parasitaemia reached the maximum on day 28 post infection. Trypanosoma infection led to significant decrease in weight gain (WG), PCV and SC. These parameters were significantly lower in infected Gudali, compared to Namchi. There was a negative correlation $(r=-0.66)$ between parasitaemia and PCV levels. Clinical signs such as fever, weakness, rough coat and weight loss were exhibited by day 28 post infection in Gudali bulls. There were significant differences between infected Gudali and Namchi for FSH and T levels. Significant negative correlations were registered between T levels and BW $(r=-0.41)$ and scrotal circumference $(r=-0.49)$.

(C) 2014 International Formulae Group. All rights reserved.
\end{abstract}

Keywords: Reproduction, body condition, trypanosomosis, cattle.

\section{INTRODUCTION}

African animal trypanosomosis is endemic in Sub Saharan Africa and a major constraint to livestock production (Abebe, 2005). Cattle, sheep, goats, pigs, horses can suffer the acute form, while dogs, cats and monkeys exhibit subclinical or chronic forms. Wild ruminants, Equidae, lions, leopards and wild pigs are known to be reservoirs of trypanosomes. The disease causes economic losses through direct mortalities, drug purchase and loss of draught power (Tesfaye et al., 2012). Annually, African breeders administer 35 million curative and preventive treatment doses (Mbahin et al., 2006). The trypanocidal drug market in West and Central Africa has been estimated at about 27 million $€$ which is equivalent to more than 17 billion CFA francs (Borne and Chevtzoff, 2013). The prevalence of the disease is about $14 \%$ in the northern region of Cameroon and varies with production systems (Achukwi and 
Musongong, 2009). The disease is caused by Trypanosoma congolense, $T$. vivax or $T$. brucei brucei, which are mostly transmitted by tsetse fly. Simultaneous infections with one or more of these trypanosomes have been reported.

The main clinical signs are anemia with a marked decrease in packed cells volume, hemoglobin, red and white blood cells (AlQarawi et al., 2004), and weight loss (Dargantes et al., 2005; Batista et al., 2009). Other signs include intermittent fever, edema, growth deficiency and even death. Infertility and testicular degeneration have been reported in camel trypanosomosis (Al-Qarawi et al., 2004).

Scrotal circumference and serum testosterone levels are indicators of the characteristics of sperm production. Indeed, recent studies in bulls (Latif et al., 2009) and bucks (Ugwu, 2009) reported that scrotal circumference had a significant positive correlation with semen volume and sperm concentration. Bulls with larger scrotal circumference had higher sperm concentration and total spermatozoa. Semen volume and scrotal circumference are also correlated to body weight in rams (Boucif et al., 2007) suggesting that small scrotal circumference could have adverse effect on testicular functions. However, the effects of the disease on some reproductive characteristics in Cameroonian cattle breeds, such as scrotal circumference and reproductive hormones rate are unknown.

The study was therefore carried out to assess the effect of experimental trypanosomosis on body weight, packed cells volume, scrotal circumference and blood levels of testosterone, Luteinizing Hormone (LH) and Follicle Stimulating Hormone (FSH) in the Gudali zebu and Namchi taurine bulls.

\section{MATERIALS AND METHODS Study area}

The study was carried out during the period of May to June 2012 in the Institute for Agricultural Research and Development at Wakwa, Ngaoundéré in the Adamawa region
(6- $8^{\circ} \mathrm{LN}$; $\left.10-12^{\circ} \mathrm{LE}\right)$ of Cameroon. The locality is known to be tsetse free.

\section{Experimental animals}

Thirty-two young bulls, aged between 3 and 5 years were selected and randomly assigned to 2 groups: control group of noninfected animals (7 Gudali and 9 Namchi) and a treatment group (7 Gudali and 9 Namchi) experimentally infected with Trypanosoma Brucei and T. Congolense strains. Prior to the experimental infection, the animals were vaccinated against prevailing diseases such as contagious bovine pleuripneumonia, pasteurollosis, lumpy skin disease and black quarter. One week before the start of the experiment, the animals were orally treated with the anthelminthic drug, albendazole at $7.5 \mathrm{mg} / \mathrm{kg}$. During experimental period, they were treated with the acaricide Cypermethrin twice a week and fed on natural pasture. Water was available ad libitum. During the study, infected animals whose PCV dropped below 20\% were treated with diminazene aceturate at $3 \mathrm{mg} / \mathrm{kg}$ by deep intramuscular injection. All the animals were treated with diminazene aceturate at $3 \mathrm{mg} / \mathrm{kg}$ at the end of the study.

\section{Experimental infection}

Trymanosoma brucei (T. brucei) and Trypanosoma congolense (T.congolense) strains were obtained from the Department of Veterinary Parasitology and Entomology of the University of Nsukka, Nigeria and transported in mice to IRAD Wakwa, Cameroon. Blood from infected mice was inoculated to two reservoir cows and parasitaemia was monitored until the level reached $10 \% \mathrm{ml}$ as described by Achukwi et al. (1997). Whole blood samples were collected from both reservoir cows. Both samples (1 $\mathrm{ml}$ ) were mixed in a beaker containing ethylenediamine tetra-acetic acid (EDTA) in 2 $\mathrm{ml}$ of phosphate buffered saline (PBS) (Achukwi et al., 1997). One $\mathrm{ml}$ of the solution was inoculated subcutaneously to each experimental animal, equivalent to the infective dose of $10^{6}$ trypanosomes. 


\section{Samples collection and testing}

The infected animals were monitored twice monthly for body weight and scrotal circumference; and weekly for parasitaemia and PCV. Scrotal circumference was measured as described by Chenoweth et al. (1992) with a flexible tape, while $5 \mathrm{ml}$ of blood was collected by jugular vein puncture in vaccutainer tubes coated with EDTA. Capillary tubes were used to determine PCV values as described by Schalm et al. (1995) and parasitaemia was detected in the same capillary tube using the buffy-coat technique (Murray et al., 1977), and quantified according to the scoring method of Herbert and Lumsden (1976).

Blood serum was obtained after centrifugation at $1500 \mathrm{rpm}$ for $5 \mathrm{~min}$ and stored at $-20{ }^{\circ} \mathrm{C}$ until laboratory analyses were carried out.

\section{Biochemical assays}

Serum testosterone was determined using DIAsource ${ }^{\circledR}$ testosterone enzyme-linked immunosorbent assay (ELISA) kit (DIAsource ImmunoAssays SA, Louvain-laNeuve, Belgium) according to the manufacturer's instructions. Each sample was analyzed in duplicate and absorbance was measured at $450 \mathrm{~nm}$ with an ELISA reader (Opsys MR, DYNEX). The range of detection was between 0.083 and $16 \mathrm{ng} / \mathrm{ml}$, with intra and inter-assay coefficients and variation of 4.16 and 9.94 respectively.

Serum FSH and $\mathrm{LH}$ were quantified using DIAsource ${ }^{\circledR}$ FSH and LH ELISA commercial kits respectively (DIAsource ImmunoAssays SA, Louvain-la-Neuve, Belgium). Optical densities of each sample were measured at $450 \mathrm{~nm}$ with an ELISA reader. Samples concentration were obtained from the standard calibration curve, constructed by plotting the mean absorbance of each calibrator against its concentration. The limits of detection ranged from 0.86-100 $\mathrm{mIU} / \mathrm{ml}$ for $\mathrm{FSH}$ and 1.27-200 $\mathrm{mIU} / \mathrm{ml}$ for LH. Intra and inter-assay coefficients of variation were 7.91 and 7.18 for $\mathrm{FSH}$, and 7.62 and 11.02 for LH respectively.

\section{Statistical analysis}

Data computed on Excel $^{\circledR}$ were analyzed by using SPSS for windows software programme Release 16.0 (2007). Weight gain was calculated as:

$$
W G=\frac{f W-i W}{i W}
$$

WG: Weight Gain; ${ }_{\mathrm{i}} \mathrm{W}$ : initial weight; ${ }_{\mathrm{f}} \mathrm{W}$ : final weight.

One way ANOVA was performed and Student t-test was used to compare means.

\section{RESULTS}

Parasitaemia score, body weight, Packed Cells Volume and scrotal circumference changes during experimental trypanosoma infection

Overall, the mean parasitaemia was significantly $(\mathrm{P}<0.05)$ higher in Gudali zebu compared to Namchi taurine (Table 1). No significant difference $(\mathrm{P}>0.05)$ was observed in body weight and PCV level between infected and non-infected animals. However, scrotal circumference was significantly lower $(\mathrm{P}<0.05)$ in trypanosoma-infected animals compared to the non-infected animals.

The body weight, PCV and scrotal circumference were significantly lower $(\mathrm{P}<0.05)$ in Trypanosome-infected Gudali zebus compared to infected-Namchi taurine. Trypanosomes were detected in the blood on day 14 post infection, and maximum parasitaemia on day 28 post infection in both groups (Figure 1) which seem to decrease faster in the Namchi taurine.

PCV values dropped significantly $(\mathrm{P}<0.05)$ during the whole infection period in Gudali zebus, and only from day 42 postinfection in Namchi taurine. By day 28 postinfection, 3 of 6 infected-Gudali zebu bulls exhibited clinical signs of the disease, including fever, weakness, rough coat and weight loss, and mean parasitaemia level was 7.8 , equivalent to $63 \times 10^{6}$ parasites $/ \mathrm{ml}$.

A negative correlation $(r=-0.66)$ was observed between parasitaemia and PCV in animals presenting clinical signs. The weight 
gain recorded in infected animals are shown in Figure 2. The mean weight gain increased by about 5\% in both Gudali zebus and Namchi taurine bulls between day 0 and day 14 postinfection and decreased in all infected animals by about $37 \%$ and $11 \%$ respectively in Gudali and Namchi bulls by day 28 post-infection.

Marked drop in weight gain in Gudali zebu and significant $(\mathrm{P}<0.05)$ increase in weight gain in Namchi taurine bulls were recorded at the end of the study.

The effects of trypanosoma infection on scrotal circumference are shown in Figure 3. There was a decline in scrotal circumference in all the animals irrespective of their breed from days 14 to 42 . From day 42, scrotal circumference continued to decrease in Gudali zebus while it increased in Namchi taurine bulls.

\section{Effects of trypanosoma infection on serum levels of $\mathrm{LH}, \mathrm{FSH}$ and testosterone}

The effect of trypanosoma infection on Luteinizing Hormone (LH), Follicle Stimulating Hormone (FSH) and Testosterone are presented in Table 2. Overall, the mean LH, FSH and testosterone concentrations were significantly lower $(\mathrm{P}<0.05)$ in infected animals compared to the non-infected animals.

No significant difference $(\mathrm{P}>0.05)$ for LH and FSH serum levels were found between infected and non-infected Gudali zebus, contrary to serum testosterone levels. Infected Namchi taurine bulls had significantly lowered values $(\mathrm{P}<0.05)$ for $\mathrm{LH}$, FSH and testosterone, compared to noninfected Namchi bulls. There were no significant differences ( $>0.05)$ between infected Gudali and Namchi for LH concentration, while differences $(\mathrm{P}<0.05)$ appeared between the latter breeds for FSH and testosterone levels.

LH values increased significantly $(\mathrm{P}<0.05)$ while $\mathrm{FSH}$ and testosterone rates showed no difference $(\mathrm{P}>0.05)$ following infection of both Gudali and Namchi bulls.

Significant negative $(\mathrm{P}<0,01)$ correlations were registered between serum testosterone level and body weight $(r=-0.41)$ and testosterone level and scrotal circumference $(r=-0.49)$. There were also non significant $(\mathrm{P}>0,05)$ negative correlations between blood testosterone concentration and PCV $(r=-0.36)$, parasitaemia $(r=-0.30)$ and LH serum level $(r=-0.11)$.

Table 1: Mean parasitaemia, body weight, packed cells volume and scrotal circumference changes in trypanoma infected and non-infected zebus and taurine bulls.

\begin{tabular}{llcccc}
\hline Bulls & & $\begin{array}{c}\text { Parasitaemia } \\
\text { (Log of } \\
\text { trypanosome } \\
\text { S/ml of } \\
\text { blood })\end{array}$ & $\begin{array}{c}\text { Mean body weight } \\
(\mathbf{k g})\end{array}$ & $\begin{array}{c}\text { Packed Cells } \\
\text { Volume } \\
(\%)\end{array}$ & $\begin{array}{c}\text { Scrotal } \\
\text { circumfe- } \\
\text { rence } \\
(\mathbf{c m})\end{array}$ \\
\hline Overall & Infected $(\mathrm{n}=16)$ & $6.7 \pm 0.6$ & $126.0 \pm 53.2^{\mathrm{a}}$ & $24.9 \pm 6.6^{\mathrm{a}}$ & $13.4 \pm 6.7^{\mathrm{a}}$ \\
& Non infected $(\mathrm{n}=16)$ & & $163.7 \pm 45.3^{\mathrm{a}}$ & $27.9 \pm 2.1^{\mathrm{a}}$ & $21.9 \pm 3.1^{\mathrm{b}}$ \\
\hline Gudali & Infected $(\mathrm{n}=7)$ & $7.2 \pm 0.5^{\mathrm{b}}$ & $86.2 \pm 31.4^{\mathrm{b}}$ & $18.7 \pm 2.9^{\mathrm{b}}$ & $7.9 \pm 2.9^{\mathrm{c}}$ \\
zebu & Non infected $(\mathrm{n}=7)$ & & $175.6 \pm 28.2^{\mathrm{c}}$ & $27.3 \pm 1.7^{\mathrm{c}}$ & $22.5 \pm 2.2^{\mathrm{d}}$ \\
\hline Namchi & Infected $(\mathrm{n}=9)$ & $6.3 \pm 0.3^{\mathrm{a}}$ & $140.0 \pm 67.4^{\mathrm{d}}$ & $28.9 \pm 2.8^{\mathrm{c}}$ & $19.0 \pm 3.9^{\mathrm{d}}$ \\
taurine & Non infected $(\mathrm{n}=9)$ & & $165.7 \pm 38.2^{\mathrm{dc}}$ & $30.4 \pm 3.0^{\mathrm{c}}$ & $20.6 \pm 4.6^{\mathrm{d}}$ \\
\hline
\end{tabular}

a,b,c,d: values in the same column with the same superscript are not different $(\mathrm{P}>0,05) ; \mathrm{n}=$ number of animals. 
Table 2: Effect of trypanosoma infection on mean LH, FSH and testosterone serum level in Gudali zebu and Namchi taurine bulls.

\begin{tabular}{llccc}
\hline Bulls & & $\begin{array}{c}\text { LH } \\
(\mathbf{m I U} / \mathbf{m l})\end{array}$ & $\begin{array}{c}\text { FSH } \\
(\mathbf{m I U} / \mathbf{m l})\end{array}$ & $\begin{array}{c}\text { Testosterone } \\
(\mathbf{n g} / \mathbf{m l})\end{array}$ \\
\hline Overall & Infected $(\mathrm{n}=11)$ & $6.21 \pm 1.40^{\mathrm{a}}$ & $4.23 \pm 0.17^{\mathrm{a}}$ & $1.63 \pm 0.17^{\mathrm{a}}$ \\
& Non infected $(\mathrm{n}=16)$ & $7.25 \pm 0.58^{\mathrm{b}}$ & $7.25 \pm 0.58^{\mathrm{b}}$ & $1.93 \pm 0.11^{\mathrm{b}}$ \\
\hline Gudali zebu & Infected $(\mathrm{n}=7)$ & $6.45 \pm 1.38^{\mathrm{c}}$ & $5.03 \pm 2.65^{\mathrm{c}}$ & $1.72 \pm 0.02^{\mathrm{c}}$ \\
& Non infected (n=8) & $6.66 \pm 0.49^{\mathrm{c}}$ & $6.28 \pm 0.28^{\mathrm{c}}$ & $1.95 \pm 0.13^{\mathrm{d}}$ \\
\hline Namchi taurine & Infected $(\mathrm{n}=4)$ & $5.69 \pm 0.16^{\mathrm{c}}$ & $7.40 \pm 0.20^{\mathrm{d}}$ & $1.51 \pm 0.22^{\mathrm{e}}$ \\
& Non infected $(\mathrm{n}=8)$ & $7.30 \pm 1.06^{\mathrm{d}}$ & $8.23 \pm 0.88^{\mathrm{e}}$ & $1.92 \pm 0.10^{\mathrm{d}}$ \\
\hline
\end{tabular}

a,b,c, d, e: values in the same column with the same superscript are not different $(\mathrm{P}>0,05)$;

$\mathrm{n}=$ number of animals.

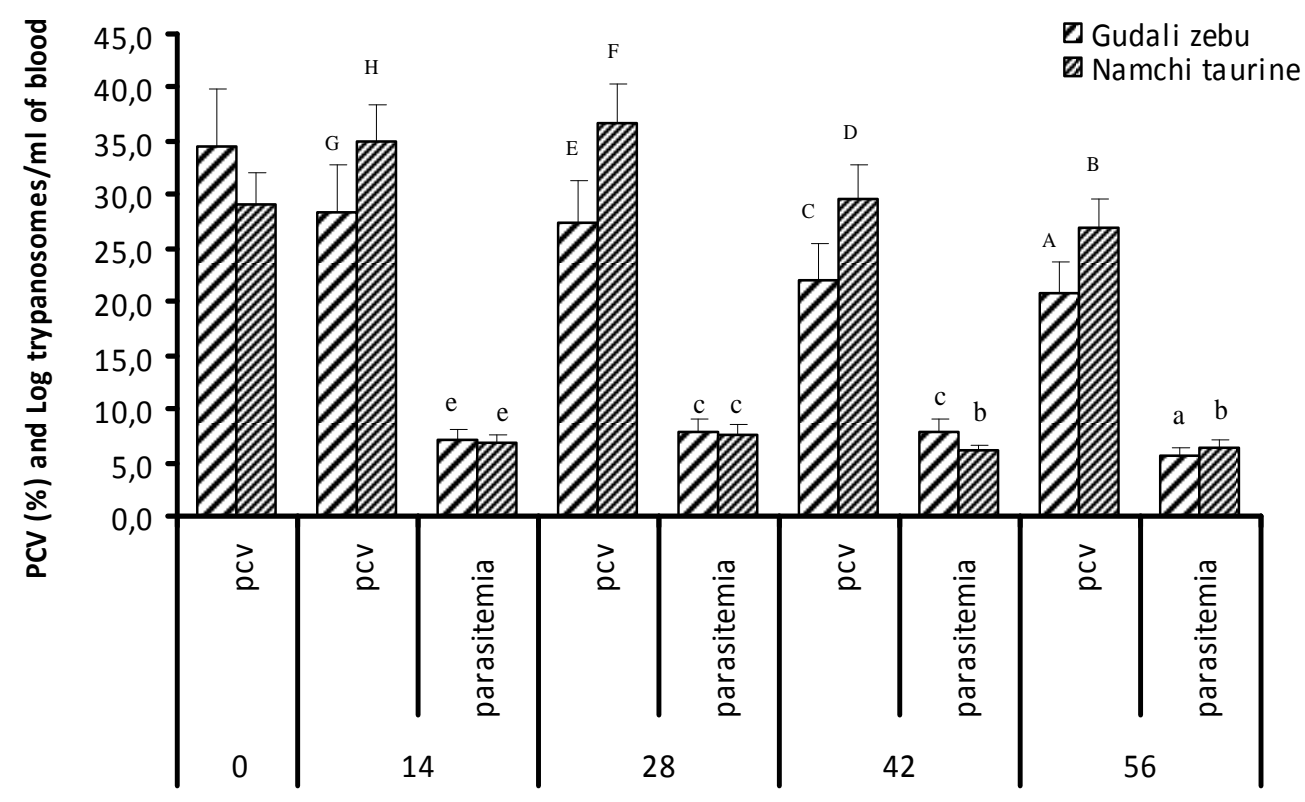

Days post-infection

Figure 1: PCV and parasitaemia score changes during trypanosoma infection in Gudali and Namchi bulls. 


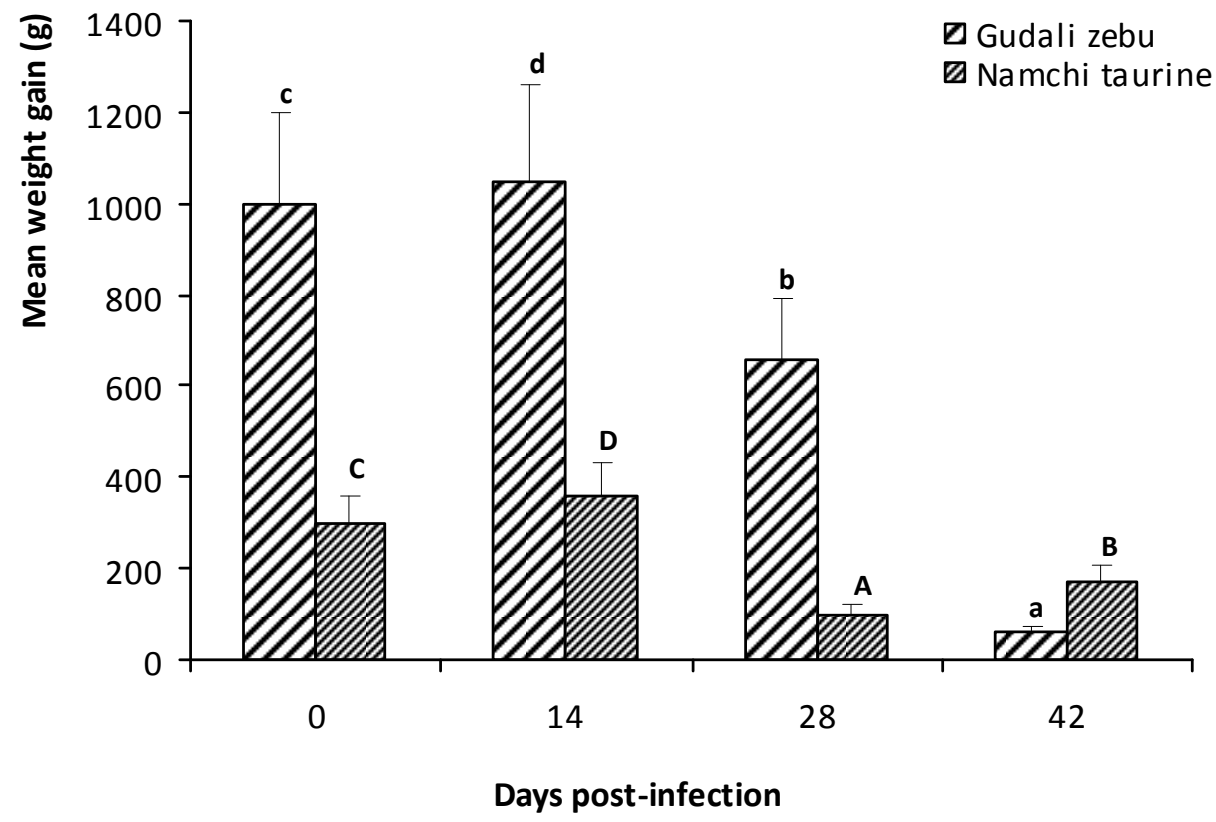

Figure 2: Mean weight gain in trypanosoma infected Gudali and Namchi bulls.

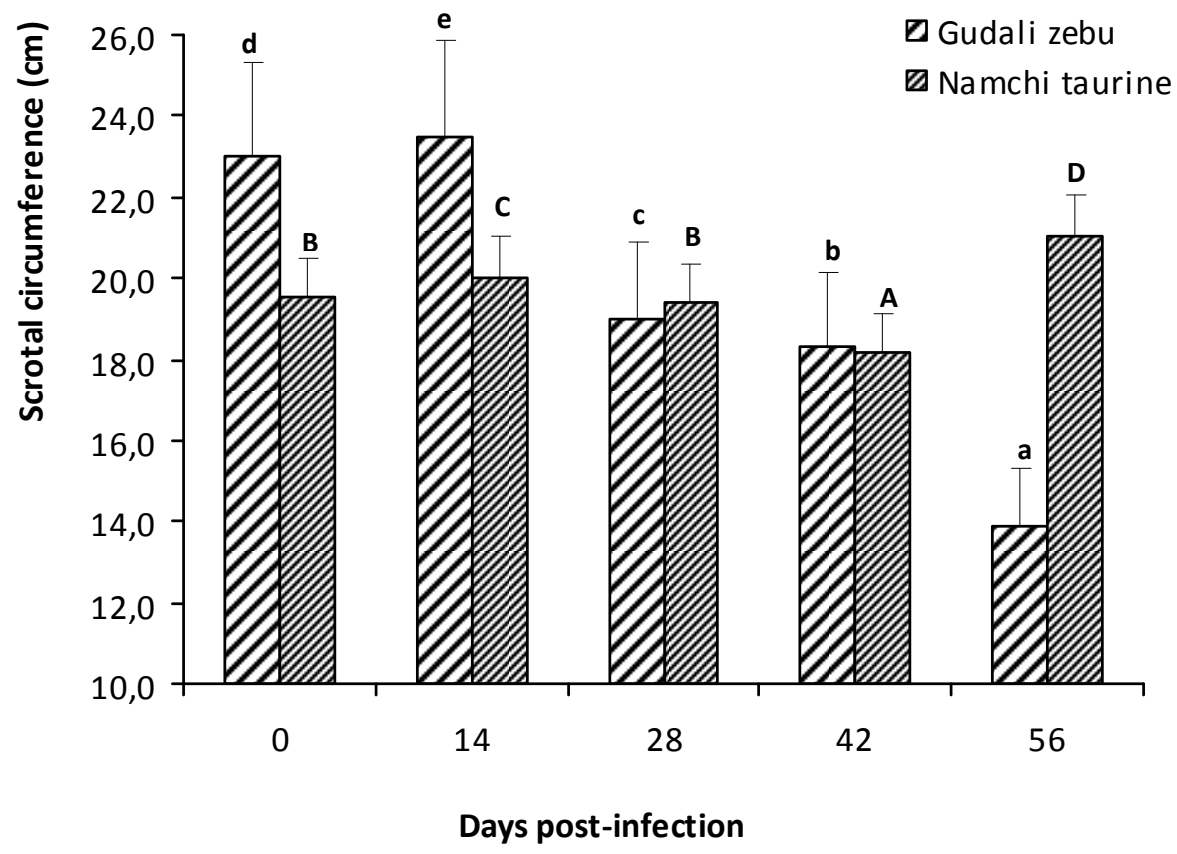

Figure 3: Scrotal circumference changes in trypanosome infected Gudali and Namchi bulls. 


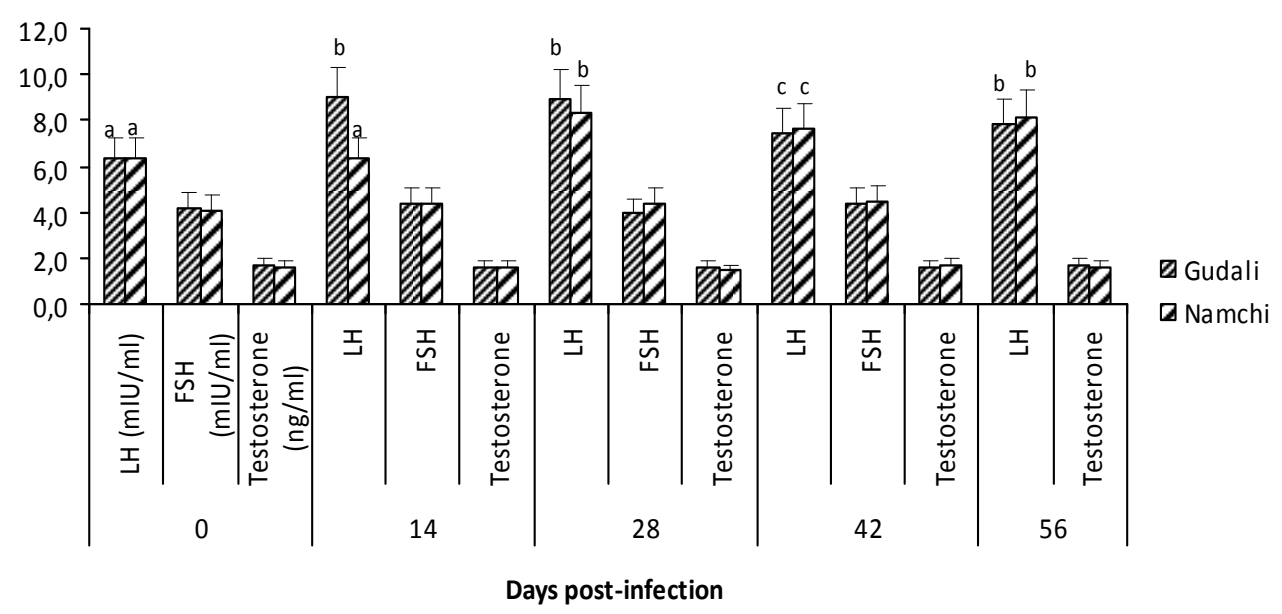

Figure 4: Serum LH (mIU/ml), FSH $(\mathrm{mIU} / \mathrm{ml})$ and testosterone $(\mathrm{ng} / \mathrm{ml})$ levels in trypanosoma infected Gudali zebu and Namchi taurine bulls.

\section{DISCUSSION}

Trypanosoma parasites were detected in the blood on day 14 post infection. However, parasitaemia has been reported to vary according to host's immune reactions, pathogen's virulence and even diagnostic methods. This could explain differences in parasites surge observed in this study. Blood trypanosomes have been recorded on day 9 after infection with simple and double concentration method, and on day 15 by direct observation technique in Baoule taurine bulls (Boly, 1993). Also, Trypanosomes were detected on the $8^{\text {th }}$ day of infection in redfronted gazelles experimentally infected with Trypanosoma brucei (Mbaya et al., 2009). Adamu et al. (2007) reported that parasitaemia occured as earlier as 5 days post infection in bulls infected with $T$. vivax and linked the early parasitaemia to immune naïvety of the young bulls.

Taylor and Authié (2004) and Mbaya et al. (2009) have reported that parasitaemia rate varied with threshold limits of $10^{3}$ to $10^{8}$ trypanosomes $/ \mathrm{ml}$. However, Talabi et al. (2012) found parasitaemia at a lower rate in Nigerian zebus infected with $T$. congolense. The difference could be with factors such as environmental stressors and single infection with $T$. congolense and to co-infections of $T$. congolense and T. brucei as carried out in our study.

In this study, parasitaemia rate also varied according to breed of the animal. Achukwi and Musongong (2009) found a similar variation in White fulani zebus and Doayo taurine cattle and Talabi et al. (2012) in Red bororo, White fulani and Sokoto goudali.

Boly (1993) reported a maximum trypanosomes concentration two weeks after infection in Baoule taurine bulls, followed by a gradual decreasing phase until the $9^{\text {th }}$ week post infection, where none of the parasite was detected. Talabi et al. (2012) observed three parasiteamia peaks on $30^{\text {th }}, 33$ and $36^{\text {th }}$ days post infection. However, the higher levels of parasitaemia occured on day 28 post infection in this study and the difference could be associated to environmental conditions, trypanosome strain, single, double or multiple infections among other factors. Additionally, trypanosomes have multiple genes that code for different surface-coat glycoproteins and are not vulnerable to the immune response (Taylor and Authié, 2004). This could also explain the different peaks observed.

Concurrent parasitic infections, such as Haemonchus contortus, have been implicated in higher parasitaemia level (Mbaya et al., 
2009) while low parasitaemia suggest the occurrence of the chronic disease.

Reduction in weight gain and drop in PCV reflected the degree of body condition and anaemia observed in this study. These findings agree with earlier results (Batista et al., 2009).

These results varied according to breed and species of animal in the present study. This is in accordance with findings in zebus in Nigeria (Talabi et al., 2012) and Ethiopia (Abebayehu and Biniam, 2010), and in West African Dwarf goats in Gambia (Faye et al., 2004).

The results of this study suggest higher sensitivity of Gudali zebus to trypanosome infection which showed a more severe anaemia, compared to a moderate anaemia in Namchi taurine. Achukwi and Musongong (2009) had described similar findings in trypanosome infected White fulani zebus and Doayo taurine in Northern-Cameroon.

However, Gachohi et al. (2009) did not find any significant difference in PCV rate between infected trypanotolerant and trypanosusceptible cattle, and explained that there was no strong association between parasitaemia and anaemia control in trypanotolerant animals.

In this study, trypanosome infection had a significant depressive effect on scrotal circumference that may cause adverse effects on sperm volume and concentration. In fact significant positive correlations have been reported between sperm volume and concentration and scrotal circumference in bulls (Latif et al., 2009) and in goats (Ugwu, 2009). Also, scrotal circumference and sperm volume correlation to body weight have been reported (Boucif et al., 2007; Boligon et al., 2011; Ejaz et al., 2011). The adverse effects of trypanosome infection on body weight and the negative consequences on scrotal circumference and sperm production was due to positive correlation between these parameters.

Although $\mathrm{LH}$ and FSH rates were lower in infected animals compared to non-infected control animals in this work, no significant differences were detected. This agrees with the results obtained by Boly (1993) in Baoule taurine bulls for LH blood level.

Mutayoba et al. (1995) had reported that $T$. brucei and $T$. congolense infections induced inflammatory injuries in the hypophysis, where hormones secretion is regulated. This could explain the lower rates of the pituitary hormones recorded in this study.

This study showed a significant lower serum testosterone levels during trypanosoma infection. This result is comparable to that of Boly (1993) in Baoule taurine bulls. Boly et al. (1991) observed a 56\% decrease in blood testosterone at the $6^{\text {th }}$ week after infection. Other studies carried out in rams infected by T. congolense (Mutayoba et al., 1995) and in camels infected with $T$. evansi (Al-Qarawi et al., 2004) also showed a depression in blood testosterone rate.

\section{Conclusion}

The study showed that experimental trypanosoma infection induced negative effects on body condition and on reproductive characteristics such as scrotal circumference and blood testosterone level. This confirmed the fact that decrease in scrotal circumference lead to a drop in blood testosterone concentration. The effect of trypanosome infection on blood LH and FSH levels need to be further clarified. This study supports the trypanosusceptibility of Gudali zebu and the trypanotolerance of Namchi taurine.

\section{ACKNOWLEDGMENTS}

The authors are grateful to the School of Veterinary Medicine and Sciences of the University of Ngaoundere for financial assistance and to staff of the Institute for Agricultural Research and Development of Wakwa for logistics.

\section{REFERENCES}

Abebayehu T, Biniam T. 2010. Bovine trypanosomosis and its vectors in two 
districts of Bench Maji zone, South Western Ethiopia, Trop. Anim. Health Prod., 42: 1757-1762.

Abebe G. 2005. Trypanosomosis in Ethiopia, Ethiopian Journal of Biomedical Sciences, 4(1): 75-121.

Achukwi MD, Musongong GA. 2009. Trypanosomosis in the Doayo/Namchi (Bos Taurus) and zebu White Fulani (Bos indicus) cattle in Faro Division, North Cameroon. Journal of Applied Biosciences, 15: 807-814.

Achukwi MD, Tanya VN, Hill EW, Bradley DG, Meghen C, Sauveroche B, Banser JT,. Ndoki JN. 1997. Susceptibility of the Namchi and Kapsiki cattle of Cameroon to trypanosome infection, Trop. Anim. Hlth Prod., 4: 219-226.

Adamu S, Fatihu MY, Useh NM, Mamman M, Sekoni VO, Esievo KA. 2007. Sequential testicular and epididymal damage in Zebu bulls experimentally infected with Trypanosoma vivax. Vet. Parasitol., 143(1): 29-34.

Al-Qarawi A, Omar H, Abdel-Rahman H, ElMougy S, El-Belely M. 2004. Trypanosomiasis-induced infertility in dromedary (Camelus dromedarius) bulls: changes in plasma steroids concentration and semen characteristics. Animal Reproduction Science, 84(1): 73-82.

Batista JS, Oliveira AF, Rodrigues CMF, Damasceno CAR, Oliveira IRS, Alves HM, Paiva ES, Brito PD, Medeiros JMF, Rodrigues AC, Teixeira MMG. 2009. Infection by Trypanosoma vivax in goats and sheeps in the Brazilian semiarid region: From acute disease outbreak to chronic cryptic infection, Veterinary Parasitology, 165(1-2):131-135.

Boligon AA, Baldi F, Galvão DAL. 2011. Genetic parameters and relationships between growth traits and scrotal circumference measured at different ages in Nellore cattle. Genetics and Molecular Biology, 34(2): 225-230.

Boly H. 1993. Effet pathogène de Trypanosoma congolense sur la fonction de reproduction mâle des taurins "Baoulé". Thèse de Doctorat d'Université, Université Pierre et Marie Curie (Paris VI), France, 101 p.

Boly H, Thiombiano D, Humblot P, Thibier M. 1991. Influence de Trypanosoma congolense sur la fonction sexuelle de taureaux Baoulé. Rev. Elev. Méd. Vét. Pays trop., 44(4): 475-480.

Borne PM, Chevtzoff C. 2013. African Animal Trypanosomosis Control Issues and Difficulties: A field analysis. Meeting between organizations involved in the integrated trypanosomosis control, Bordeaux, 26 April 2013, 16 p.

Boucif A, Azzi N, Tainturier D, Niar A. 2007. Variations saisonnières des paramètres reproductifs chez les béliers de deux races locales algériennes. Renc. Rech. Ruminants, 14.

Chenoweth PJ, Spitzer JC, Hopkins FM. 1992. A new bull breeding soundness evaluation form. Proc. Ann. Mtng. Soc. for Theriogenology San Antonio, TX. pp. 63-71.

Dargantes AP, Reid SA, Copeman DB. 2005. Experimental Trypanosoma infection in the goat. Clinical signs and clinical pathology. Journal of Comparative Pathology, 133(4): 261-266.

Ejaz A, Nasim A, Zahid N, Muhammad A, Muhammad SK, Muhammad A, Muhammad Y. 2011. Relationship of age to body weight, scrotal circumference, testicular ultrasonograms, and semen quality in Sahiwal bulls. Trop Anim Health Prod., 43: 159-164.

Faye D, Sulon J, Kane Y, Beckers JF, Leak S, Kaboret Y, De Sousa NM, Losson B, Geerts S. 2004. Effects of an experimental Trypanosoma congolense infection on the reproductive performance of West African Dwarf goats. Theriogenology, 62(8): 1438-1451.

Gachohi JM, Bett B, Murilla GA. 2009. Factors influencing the prevalence of trypanosomosis in Orma Boran (trypanotolerant) and Teso zebu 
(trypanosusceptible) cattle crosses in Teso District, western Kenya. Livestock Research for Rural Development, 21(12), www.lrrd.org/lrrd21/12/cont2112.htm

Herbert WJ, Lumsden WHR. 1976. Trypanosoma brucei: A rapid "matching" method for estimating the host's parasitaemia. Experimental Parasitology, 40: 427-431.

Latif MA, Ahmed JU, Bhuiyan MMU, Shamsuddin. 2009. Relationship between scrotal circumference and semen parameters in crossbred bulls. Bangl. Vet., 2(26): 61-67.

Mbahin N, Zoli A, Mamoudou A, Tanenbe C, Abah S, Ghogumu RT, Nouala SF, Njeumi F. 2006. Livestock owners perception on trypanosomosis and associated treatment on the Adamaoua plateau in Cameroon ten years after tsetse eradication. Bulletin of Animal Health and Production in Africa, 54: 260-270.

Mbaya AW, Aliyu MM, Nwosu CO, EgbeNwiyi T. 2009. The relationship between parasitaemia and anaemia in concurrent Trypanosoma brucei and Haemonchus contortus infections in red fronted gazelles (Gazella rufi frons), Veterinarski Arhiv, 79(5): 451-460.

Murray M, Murray PK, McIntyre WIM. 1977. An improved parasitological technique for the diagnosis of African trypanosomosis. Transactions of the Royal Society of Tropical Medicine and Hygiene, 71: 325-326.
Mutayoba BM, Eckersall PD, Jeffcoate IA, Cestnik V, Holmes PH, Reid SWJ. 1995. Alterations in plasma luteinising hormone and testosterone concentrations and responses to injection of gonadotrophinreleasing hormone in sheep infected with Trypanosoma congolense, Animal Reproduction Science, 40: 203-214.

Schalm OW, Jain NC, Carrol J. 1995. Veterinary Haematology $\left(3^{\text {rd }}\right.$ edn). Lea and Febiger: Philadelphia; 498-512.

Talabi AO, Otesile EB, Joshua RA, Oladosu LA. 2012. Clinical observations on three Nigerian zebu cattle breeds following experimental Trypanosoma congolense infection. Bull. Anim. Hlth. Prod. Afr., 60: 187-192.

Taylor K, Authié EML. 2004. Pathogenesis of Animal Trypanosomiasis In Maudlin I, Holmes PH, Miles MA (eds). The Trypanosomiasis, CAB International Publishing: Wallingford Oxford shire OX 18 DE. UK; 331-353.

Tesfaye D, Speybroeck N, De Deken R, Thys E. 2012. Economic burden of bovine trypanosomosis in three villages of Metekel zone, Northwest Ethiopia, Trop Anim Health Prod., 44: 873-879.

Ugwu SOC. 2009. Relationship between scrotal circumference, in situ testicular measurements and sperm reserves in the West African dwarf bucks. Afr. J. Biotechnol., 8(7): 1354-1357. 